JURNAL PENDIDIKAN USIA DINI

DOI: https://doi.org/10.21009/JPUD.122
DOI: $\underline{\text { https://doi.org/10.21009/JPUD.122.12 }}$

\title{
ANALISIS GERAK DASAR ANAK USIA 6-7 TAHUN
}

\author{
Rama Kurniawan \\ Fakultas Ilmu Keolahragaan, Universitas Negeri Malang, Indonesia \\ E-mail: rama.kurniawan.fik@um.ac.id
}

\begin{abstract}
ABSTRAK
This study aims to know the students' fundamental movement ability and to analyze those movements based on gender. It was conducted in SDN 1 Lemahabang Kulon, Cirebon Regency. The subject involved in this study was 24 students of the lower-primary levels in the school whose ages between 6-7 years old. Data collection method applied was the observation of the students' fundamental movements. The assessment form on fundamental movement (Gallahue :1996) was used as the instrument of the study. The data was analyzed using a descriptive quantitative technique with a percentage. The finding shows that it was only $65.6 \%$ students who properly mastered the fundamental movement of stability. Meanwhile, the fundamental movements of locomotor and manipulative were mastered only by $43 \%$ and $41.7 \%$. Based on the gender analysis, the male students were better on fundamental movements than the female ones. To facilitate the future success of movement on students, it is suggested to have a directional and specific program on movement development.
\end{abstract}

Keywords:, Early childhood, Fundamental movement

Penelitian ini bertujuan untuk mengetahui kemampuan gerak dasar siswa serta menganalisa gerakan tersebut berdasarkan gender. Penelitian ini dilakukan di SDN 1 Lemahabang Kulon Kabupaten Cirebon. Subyek yang terlibat dalam penelitian adalah siswa sekolah dasar kelas rendah yang berusia 6-7 tahun yang berjumlah 24 anak. Pengumpulan data dalam penelitian ini menggunakan kegiatan observasi terhadap gerakan dasar siswa. Instrumen yang digunakan adalah format penilaian gerak dasar. Analisis data yang digunakan adalah deskriptif kuantitatif dengan menggunakan persentase. Hasil penelitian menunjukkan bahwa hanya $65.6 \%$ siswa yang menguasai dengan baik gerak dasar non-lokomotor. Sedangkan gerak dasar lokomotor dan manipulatif hanya $43 \%$ dan $41.7 \%$. Berdasarkan analisis gender, siswa laki-laki memiliki kemampuan gerak dasar yang lebih baik daripada siswa perempuan. Untuk mendukung kesuksesan gerak siswa di masa mendatang, diperlukan program pengembangan gerak yang terarah dan spesifik.

Kata Kunci: Anak usia dini, Gerak dasar

\section{PENDAHULUAN}

Perkembangan gerak (motorik) yang dialami oleh manusia merupakan perubahan yang terjadi terus menerus sepanjang hidup (Gallahue, D.L \& Ozmun, 1998). Pertumbuhan dan perkembangan tersebut banyak berlangsung di masa anak-anak dan remaja. Oleh karena itu, menjadi penting untuk terus memperhatikan proses pertumbuhan dan perkembangan mereka. Proses pertumbuhan dan perkembangan yang terjadi pada anak usia dini terutama pada penguasaan keterampilan gerak 
dasar sangat menentukan kesuksesan gerak motorik di masa selanjutnya.

Hasil tinjauan Bremer \& Cairney menyimpulkan bahwa empat dari lima hasil studi mengindikasikan adanya korelasi positif antara keterampilan gerak dasar dengan akifitas fisik (Bremer, E. \& Cairney, 2016). Jika anak memiliki keterampilan gerak dasar yang baik maka hal tersebut akan mendorong pola konsistensi mereka dalam melakukan aktifitas fisik. Selanjutnya aktivitas fisik yang dilakukan secara berkala inilah yang akan mendorong kualitas hidup sehat serta pada akhirnya akan membantu mereka dalam tugas gerak sehari-hari. Kajian dengan hasil serupa juga dilakukan oleh Barnett, dkk menyatakan bahwa kemampuan gerak motorik yang dimiliki oleh anak akan menentukan kebiasaan mereka dalam melakukan aktifitas fisik pada saat remaja (Barnett, L.M., Beurden, E., Morgan, P.J., Brooks, L.O., Beard, 2009). Berdasarkan beberapa hasil penelitian tersebut, keterampilan gerak dasar (motorik) menjadi sangat penting untuk diajarkan kepada siswa sekolah dalam rangka membekali mereka untuk menghadapi tantangantantangan aktifitas fisik dalam hidupnya.

Dalam kajian lain, penguasaan gerak motorik yang baik juga terbukti memiliki peran penting bagi anak. Kajian meta analisis yang dilakukan oleh Engel, dkk. menunjukkan bahwa latihan keterampilan motorik yang rutin dilakukan oleh siswa selain berkontribusi positif terhadap aktivitas fisiknya juga mampu mengurangi potensi obesitas pada anak usia dini (Engel, A.C., Broderick, C.R., Doorn, N., Hardy, L.L., \& Parmenter, 2018). Sedangkan hasil analisis Lubans, dkk. menyatakan bahwa kemampuan gerak dasar akan memiliki beberapa manfaat diantaranya terkait dengan konsep diri, perasaan terhadap kemampuan fisik yang dimiliki (perceived physical competence), kebugaran otot, ketahanan sistem pernapasan dan jantung, kelenturan tubuh, berat badan serta mengurangi sedentarism (kurang gerak) (Lubans, D.R., Morgan, P.J., Cliff, D.P., Barnett, 2010). Hal serupa juga disampaikan oleh Hands bahwa kemampuan gerak dasar pada anak berperan aktif terhadap perkembangan fisik, sosial dan kesehatan emosional baik dalam jangka pendek maupun jangka panjang (Hands, 2012).

Menyadari akan pentingnya perkembangan gerak dasar anak selanjutnya mendorong peneliti untuk melakukan pengamatan mengenai kondisi perkembangan gerak dasar siswa pada kelas rendah sekolah dasar. Penelitian ini bertujuan untuk memperoleh gambaran mengenai perkembangan kemampuan gerak dasar siswa Sekolah Dasar (SD) terutama pada usia 6-7 tahun 


\section{KAJIAN TEORITIK}

\section{Fundamental Movement}

Kemampuan gerak (movement abilities) adalah istilah yang menggabungkan tiga kategori gerak yaitu non-lokomotor (stability), lokomotor, dan manipulatif (object control). Salah satu yang bisa dipelajari dari aspek perilaku motorik adalah kaitannya dengan pemahaman terhadap gerak yang ditampilkan serta bagaimana tampilan gerak tersebut ketika dipengaruhi oleh usia, gender, dan kelas sosial (Gallahue, D.L \& Ozmun, 1998). Gerak manusia dalam kesehariannya terbagi menjadi beberapa bentuk diantaranya gross movements (gerak motorik kasar), fine movements (gerak motorik halus), discrete movements (gerak diskrit), serial movements (gerak seri), continuous movements (gerak berkelanjutan), open movements (gerak terbuka), dan closed movements atau gerak tertutup (Schmidt, R.A, Wrisberg, 2000).

Menurut Gallahue gerak yang dapat diamati dapat digolongkan ke dalam tiga bentuk gerak (Gallahue, 1996), yaitu:

a. stabilizing movement

stabilizing movement atau gerak non-lokomotor adalah gerak yang menempatkan diri pada posisi tubuh diam, menyeimbangkan tubuh terhadap gaya gravitasi. Beberapa gerak yang termasuk ke dalam kategori ini adalah a) beam walk b) one-foot balance, c) body rolling, dan d) dodging

b. locomotor movement locomotor movement atau gerak lokomotor adalah gerak perubahan posisi tubuh dari satu tempat ke tempat yang lain. Beberapa gerak yang termasuk ke dalam kategori ini adalah a) running, b) leaping, c) horizontal jumping, d) vertical jumping, e) jumping from a height, f) hoping, g) galloping dan sliding, dan h) skipping

c. Manipulative movement manipulative movement atau gerak manipulatif adalah gerak yang memberi atau menerima sebuah objek atau benda tertentu.

Beberapa gerak yang termasuk ke dalam kategori ini adalah a) throwing, b) catching, c) kicking, d) trapping, e) dribling, f) ball rolling, g) striking, h) volleying

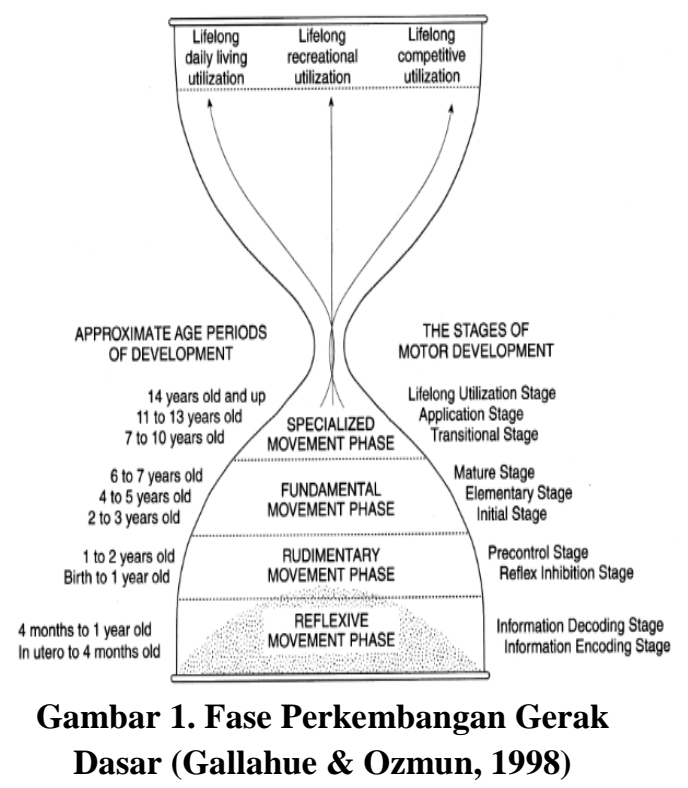




\section{Fase Perkembangan Gerak}

Perkembangan motorik pada manusia diawali dengan fase gerak refleks (reflexive movement phase) yang terjadi pada bayi dalam kandungan hingga berumur 1 tahun dan diakhiri dengan fase gerak khusus (specialized movement phase) yang terjadi pada umur 14 ke atas. Secara jelas digambarkan seperti pada gambar 1. Fase selanjutnya adalah fundamental movement abilities atau kemampuan gerak dasar dimana anak secara aktif belajar dan melatih kemampuan gerak dari tubuh mereka Pada fase inilah mereka kemudian mempelajari bagaimana melakukan berbagai gerakan non-lokomotor, lokomotor, dan manipulatif secara terpisah dan berkesinambungan menggabungkannya dengan gerakangerakan lain.

Beberapa peneliti dan para pengembang instrumen penilaian berusaha membagi gerak dasar ke dalam tiga tingkatan (Gallahue, D.L \& Ozmun, 1998) yaitu:

\section{Initial stage}

Pada tingkatan ini terlihat gerakan masih belum utuh, terlihat masih terbatas dalam penggunaan tubuh, serta minimnya gerakan ritmik dan koordinasi antar bagian tubuh. Yang tergolong pada tingkatan ini adalah anak usia 2 tahunan.

2. Elementary stage

Pada tingkatan ini, kontrol gerak dan koordinasi ritmik sudah lebih baik dibandingkan dengan tingkatan sebelumnya. Namun pola gerak yang dilakukan masih kurang leluasa meskipun sedikit lebih terorganisir. Yang tergolong pada tingkatan ini adalah anak usia 3 atau 4 tahunan.

\section{Proficient/Mature stage}

Pada tingkatan ini penampilan motorik sudah terkoordinasi dan gerak lebih efisien. Anak pada usia 5-6 tahun umumnya sudah pada tahapan ini dan mungkin gerak manipulatif seperti melempar memukul dan menangkap memang bekembang agak lambat. Hal tersebut disebabkan karena aktivitas-aktivitas tersebut memang membutuhkan kemampuan visual-motor yang agak rumit.

Perkembangan gerak pada anak usia 6-7 tahun atau seringkali disebut pada fase akhir anak usia dini tahun juga berada pada tingkatan mature. Gerakan-gerakan lokomotor, non lokomotor serta manipulatif mulai berkembang dengan baik. Setiap perkembangan tersebut harus benarbenar dipastikan agar mendukung segala aktivitas sepanjang hayat mereka.

\section{METODOLOGI PENELITIAN}

Metode yang digunakan dalam penelitian ini adalah deskriptif kuantitatif. Peneliti melakukan observasi keterampilan gerak dasar pada sampel penelitian yang telah dipilih. Pelaksanaan observasi sendiri dilakukan di Sekolah Dasar Negeri 1 Lemahabang Kulon, Cirebon, Jawa 
Barat. Teknik pengambilan subjek penelitian menggunakan cara purposive random sampling yaitu disesuaikan dengan kriteria kelas rendah sekolah dasar tersebut mulai dari kelas 1 hingga kelas 3. Sampel penelitian yang terpilih adalah kelas I B dari dua kelas yang tersedia yaitu I A dan I B. Sampel terdiri dari 11 siswa laki-laki dan 13 Perempuan (jumlah siswa 24) dengan kisaran umur antara 6-7 tahun.

Instrumen yang digunakan dalam penelitian ini adalah format motor assessment (Gallahue, 1996). Format ini terdiri dari item-item gerak dasar (non-lokomotor, lokomotor maupun manipulatif). Rentang skala penilaiannya berupa pemberian nilai 3 untuk gerakan yang termasuk kategori baik, nilai 2 untuk gerakan yang termasuk kategori sedang, dan nilai 1 untuk kategori gerakan kurang. Teknik pengumpulan data yang dilakukan adalah dengan melakukan tes keterampilan gerak dasar nonlokomotor, lokomotor dan manipulatif pada siswa.

Masing-masing siswa diminta untuk mempraktikan gerakan nonlokomotor yaitu beam walk, one-foot balance, body rolling, dodging, gerakan lokomotor yaitu running, leaping, horizontal jumping, vertical jumping, jumping from a height, hoping, galloping and sliding, skipping dan gerakan manipulatif yaitu throwing, catching, kicking, trapping, dribling, ball rolling, striking, volleying. Setiap melakukan semua gerakan tersebut sesuai dengan kemampuan mereka. Pada saat yang sama, observer mengamati pola gerakan siswa dan melakukan penilaian sesuai dengan petunjuk pengisian format observasi. Analisis data yang digunakan yaitu dengan cara menghitung persentase dari tampilan kemampuan gerak dasar baik individu maupun kemampuan gerak secara kelompok. Analisis kemampuan gerak juga dilakukan berdasarkan faktor gender yaitu hasil tampilan gerak pada siswa laki-laki maupun siswa perempuan.

\section{HASIL DAN PEMBAHASAN}

Analisa hasil penelitian dilakukan untuk menjawab tujuan penelitian yaitu melihat perkembangan keterampilan gerak dasar siswa pada usia 6-7 tahun. Deskripsi data yang disajikan berupa deskripsi data dari masing-masing gerakan dasar yang dikelompokkan menjadi gerak dasar non-lokomotor, lokomotor dan manipulatif. Deskripsi data gerak dasar siswa bisa dijabarkan seperti pada tabel 1. Dari paparan tabel tersebut dapat diketahui bahwa persentase keterampilan gerak dasar non-lokomotor seluruh siswa pada pada kisaran $50 \%-75 \%$ atau dalam kategori baik Sedangkan persentase gerak dasar non-lokomotor siswa berkisar antara $4.2 \%-8.3 \%$ atau kategori kurang. Dari hasil observasi tersebut diperoleh gambaran spesifik bahwa dodging merupakan gerakan yang paling dikuasai oleh siswa. Hal 
tersebut terlihat dari persentase penguasaan siswa yang sebesar $75 \%$. Sedangkan body rolling dan one-foot balance menjadi gerak dasar nonlokomotor yang paling kurang dikuasai oleh siswa. Angka persentase kedua gerakan tersebut berada pada kisaran angka yang sama yaitu $8.3 \%$.

Tabel 1. Deskripsi Data Hasil Kemampuan Gerak Dasar Siswa

\begin{tabular}{|c|c|c|c|c|c|c|c|c|}
\hline \multirow[t]{2}{*}{ Skill } & & \multicolumn{2}{|c|}{$\begin{array}{c}\text { Skor } \\
\text { maksimal }\end{array}$} & \multicolumn{2}{|c|}{$\begin{array}{c}\text { Skor } \\
\text { rata-rata }\end{array}$} & \multicolumn{3}{|c|}{ Kriteria (\%) } \\
\hline & & $\mathrm{L}$ & $\mathrm{P}$ & L & $P$ & Baik & Sedang & Kurang \\
\hline $\begin{array}{l}\text { Bgt } \\
55\end{array}$ & & 28 & 36 & 2.55 & 2.77 & 70.8 & 25 & 4.2 \\
\hline One Foot Balance & 要 & 32 & 30 & 2.91 & 2.31 & 66.7 & 25 & 8.3 \\
\hline Body Rolling & $4 \frac{5}{0}$ & 29 & 29 & 2.64 & 2.23 & 50 & 41.7 & 8.3 \\
\hline Dodging & & 30 & 35 & 2.73 & 2.69 & 75 & 20.8 & 4.2 \\
\hline Rumning & & 30 & 27 & 2.73 & 2.08 & 41.6 & 54.2 & 4.2 \\
\hline Leaping & & 21 & 29 & 1.91 & 2.23 & 20.8 & 66.7 & 12.5 \\
\hline Horizontal Jump & & 27 & 32 & 2.45 & 2.46 & 58.3 & 29.2 & 12.5 \\
\hline Vertical Jimp & 5 & 24 & 29 & 2.18 & 2.23 & 33.3 & 54.2 & 12.5 \\
\hline Jiomp fiom a Height & & 24 & 28 & 2.18 & 2.15 & 25 & 66.7 & 8.3 \\
\hline Hopping & 总 & 31 & 34 & 2.82 & 2.62 & 75 & 20.8 & 4.2 \\
\hline Galloping & & 23 & 24 & 2.09 & 1.85 & 83 & 79.2 & 12.5 \\
\hline Sliding & & 28 & 32 & 2.55 & 2.46 & 54.2 & 41.6 & 4.2 \\
\hline Skipping & & 32 & 33 & 2.91 & 2.54 & 70.8 & 29.2 & 0 \\
\hline Throwing & & 24 & 29 & 2.18 & 2.23 & 25 & 70.8 & 4.2 \\
\hline Catching & & 28 & 34 & 2.55 & 2.62 & 70.8 & 16.7 & 12.5 \\
\hline Kicking & & 28 & 27 & 2.55 & 2.08 & 33.3 & 62.5 & 4.2 \\
\hline Trapping & $\frac{\vec{\omega}}{\vec{\sigma}}$ & 30 & 33 & 2.73 & 2.54 & 70.8 & 20.9 & 8.3 \\
\hline Dribbling & $\bar{a}$ & 28 & 27 & 2.55 & 2.08 & 33.3 & 62.5 & 4.2 \\
\hline Ball rolling & 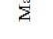 & 31 & 34 & 2.82 & 2.62 & 75 & 20.8 & 4.2 \\
\hline Striking & & 23 & 27 & 2.09 & 2.08 & 125 & 83.3 & 4.2 \\
\hline Volleying & & 18 & 26 & 1.64 & 2.00 & 12.5 & 58.3 & 29.2 \\
\hline
\end{tabular}

Pada kategori gerak dasar lokomotor, gerakan hopping adalah gerakan yang paling baik dikuasai oleh siswa. Hal ini didasarkan pada angka persentase sebesar $75 \%$. Selanjutnya diikuti gerakan skipping pada kisaran angka $70.8 \%$, dan sliding pada angka $54.2 \%$. Sedangkan pada kategori gerak dasar lokomotor yang terlihat kurang dikuasai oleh siswa adalah gerakan leaping, galloping, horizontal jump dan vertical jump. Masing-masing gerakan tersebut berada pada angka persentase yang sama yaitu sebesar $12.5 \%$.

Untuk kategori gerak dasar manipulatif, gerakan ball rolling memiliki angka persentase sebesar $75 \%$ yang kemudian bisa dikatakan gerakan yang paling dikuasai oleh siswa. Sedangkan gerakan volleying menjadi gerakan yang paling kurang dikuasai oleh siswa. Hal ini terlihat dari hasil observasi yang hanya menunjukkan angka persentase sebesar $29.2 \%$.

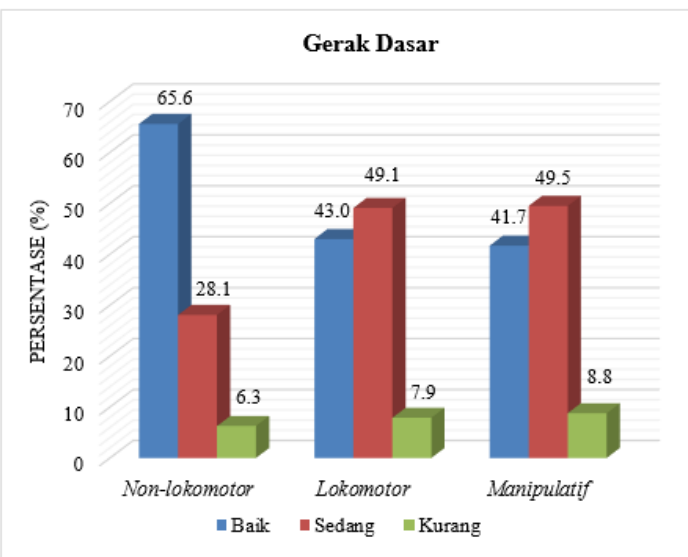

\section{Grafik 1. Persentase Kemampuan Gerak Dasar Siswa \\ Secara keseluruhan ketiga} kelompok gerak dasar dapat dilihat pada tampilan Grafik 1. Kategori gerakan manipulatif menjadi kategori gerak dasar yang paling kurang dikuasai oleh siswa. Hal ini didukung dengan data yang menunjukkan angka persentase sebesar $41.7 \%$ (kategori baik) dan angka $8.8 \%$ (kategori kurang). 
Analisis Gerak Dasar Anak Usia 6-7 Tahun Rama Kurniawan

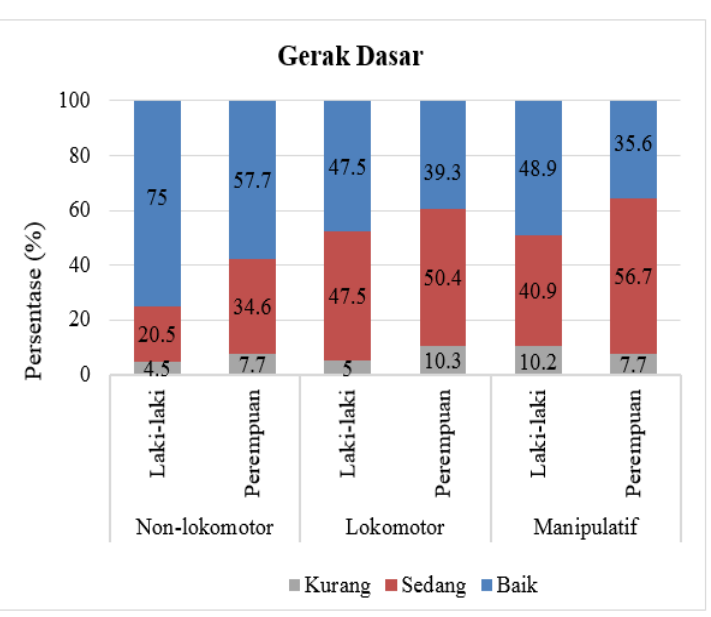

Grafik 2. Persentase Kemampuan Gerak Dasar Siswa Berdasarkan Gender

Gerakan non-lokomotor menjadi kategori gerak yang paling dikuasai oleh siswa. Berdasarkan grafik di atas angka persentase menunjukkan kategori baik sebesar $65.6 \%$ dan kategori kurang yaitu hanya sebesar $6.3 \%$.

Penampilan gerak pada anak cenderung dipengaruhi oleh beberapa hal. Faktor biologis dan faktor lingkungan turut mengiringi penampilan gerak sesorang. Masa pubertas (hormon) dan karakteristik bentuk tubuh dan menjadi hal yang dianggap mempengaruhi tampilan gerak mereka. Selanjutnya orang tua menjadi faktor lingkungan pertama yang akan mempengaruhi pilihan gerak anak. Pada masa anak-anak memasuki usia sekolah, teman sebaya (peers) dan guru ikut menciptakan pandangan serta kebiasaan anak dalam bergerak (Thomas, J.R. \& French, 1985). Hasil review dari beberapa penelitian oleh Jenkinson, dkk serta Houston-Wilson, dkk sepakat menyatakan bahwa peningkatan perkembangan keterampilan gerak anak di sekolah juga dipengaruhi oleh pemberian bantuan teman sebaya (peers) (Jenkinson, K., Bendon, A.C., \& Naughton, 2013) (Houston-Wilson, C., Dunn, J.M., van der Mars, H., \& McCubbin, 1997).

Perkembangan kemampuan gerak dasar pada anak, tentu sangat erat kaitannya dengan dengan gender. Konsep pengaruh gender pada gerak anak tersebut kemudian direspon dengan berbagai macam penelitian. Penelitian-penelitian tersebut banyak digunakan untuk menjelaskan hubungan maupun perbedaan penguasan gerak dasar antara siswa laki-laki dan perempuan di tingkat sekolah dasar. Beberapa fakta penelitian memperlihatkan adanya perbedaan penguasaan gerak dasar berdasarkan gender terutama pada penguasaan gerak dasar manipulatif. Seperti penelitian Iivonen \& Sääkslahti yang telah melakukan kajian terhadap penelitian longitudinal dan cross sectional (Iivonen, S. \& Sääkslahti, 2013). Hasil yang diperoleh yaitu sebagian besar menyatakan bahwa anak lakilaki memiliki kecenderungan penguasaan kemampuan gerak dasar manipulatif yang lebih baik jika dibandingkan dengan anak perempuan. Adanya keseragaman temuan tersebut salah satunya didasarkan pada perbedaan pola aktivitas yang dilakukan oleh kedua 
gender tersebut baik di selama di sekolah maupun di luar sekolah. Siswa laki-laki memiliki kecenderungan lebih banyak melakukan aktifitas fisik di luar ruang (outdoor) dibandingkan dengan siswa perempuan. Salah satu aktvitas dominan yang dilakukan yaitu aktivitas olahraga (Bailey, R., Wellard, I. \& Dismore, 2005).

Perbedaan kemampuan tersebut memberikan tantangan tersendiri bagi guru. Program yang disusun haruslah yang memperhatikan kekhasan dan keunikan dari masing-masing kelompok siswa. Program yang dirancang harus benar-benar didasarkan pada karakteristik tingkat perkembangan anak developmentally appropriate program (Buschner, 1994). Berdasarkan DAP, program pembelajaran yang dirancang harus memperhatikan penglaman gerak yang sudah didapat oleh siswa sebelumnya. Program juga hendaknya disusun dengan memperhatikan perbedaan kemampuan gerak masing-masing siswa. Dengan demikian, diharapkan masing-masing siswa memiliki kesempatan yang sama dalam meraih kesuksesan geraknya.

\section{KESIMPULAN DAN SARAN}

Sesuai dengan poin-poin pembahasan yang telah diuraikan sebelumnya, ada beberapa hal yang dapat disimpulkan yaitu kondisi perkembangan gerak dasar siswa di sekolah subjek penelitian belum begitu baik. Hal ini dibuktikan dengan hasil analisis gerak yang yang menyatakan keseluruhan siswa memiliki gerak dasar lokomotor dan manipulatif yang berada pada kategori kurang.

Hasil tersebut perlu mendapat perhatian khusus bagi pendidik, orang tua maupun sekolah. Ketiga elemen tersebut memiliki tanggungjawab dalam mendesain ulang strategi dan program yang diharapkan mampu meningkatkan perkembangan gerak dasar pada siswa Program yang disiapkan hendaknya juga memperhatikan perbedaan kemampuan awal yang dimiliki oleh siswa laki-laki maupun perempuan. Selanjutnya penelitian ini memiliki beberapa keterbatasan diantaranya terkait dengan penggunaan sample size. Penelitian serupa di masa mendatang hendaknya dapat menggunakan sampel yang lebih banyak dan lebih luas sehingga hasil kajian bisa digunakan untuk menggeneralisasikan populasi (effect size) yang lebih luas. Peneliti lain yang ingin menganalisis fokus penelitian yang sama yaitu gerak dasar anak usia 6-7 tahun mungkin bisa menggunakan alternatif instrumen TGMD-3 (Test of Gross Motor Development - 3) yang dikembangkan oleh Ulrich (2013). Penelitian di masa mendatang juga diharapkan bisa mengkaji lebih dalam mengenai faktor-faktor dominan yang mempengaruhi penguasaan gerak dasar siswa anak usia dini. 


\section{DAFTAR PUSTAKA}

Bailey, R., Wellard, I. \& Dismore, H. (2005). Girls' Participation in Physical Activities and Sports: Benefits, Patterns, Influences and Ways Forward. Centre for Physical Education and Sport Research. Canterbury Christ Church University College, U.K. for the World Health Organisation (WHO).

Barnett, L.M., Beurden, E., Morgan, P.J., Brooks, L.O., Beard, J. R. (2009). Childhood Motor Skill Proficiency as a Predictor of Adolescent Physical Activity. Journal of Adolescent Health., 44 (3), 252259.

Bremer, E. \& Cairney, J. (2016). Fundamental Movement Skills and Health-Related Outcomes: A Narrative Review of Longitudinal and Intervention Studies Targeting Typically Developing Children. American Journal of Lifestyle Medicine, 12 (2), 1-12.

Buschner, C. A. (1994). Teaching Children Movement Concept and Skills: Becaming a Master Teacher. Champaign: Human Kinetics Publisher.

Engel, A.C., Broderick, C.R., Doorn, N., Hardy, L.L., \& Parmenter, B. J. (2018). Exploring the Relationship Between Fundamental Motor Skill Interventions and Physical Activity Levels in Children: A Systematic Review and Meta-analysis. Sports Medicine, 1-13.

Gallahue, D.L \& Ozmun, J. C. (1998). Understanding; $\quad$ Motor Development: Infants, Children, Adolescents, Adults. USA: The Mc Graw Hill Companies.
Gallahue, D. L. (1996). Developmental Physical Education for Today's Children. Indiana University and National Institute for Fitness and Sport: Brown \& Benchmark.

Goodway, J.D., Crowe, H., \& Ward, P. (2003). Effect of Motor Skill Instruction on Fundamental Motor Skill Development. Adapted Physical Activity Quarterly, 20, 296-314.

Hands, B.P. \& Martin, M. (2003). Implementing a Fundamental Movement Skill Program in an Early Childhood Setting: The Children's Perspectives. Australian Journal of Early Childhood, 28(4), 47-52.

Hands, B. P. (2012). How fundamental are fundamental movement skills? Active and Healthy Magazine, 19(1), 11-13.

Hardy, L.L., King, L., Farrell, L., Macniven, R., Howlett, S. (2010). Fundamental Movement Skill among Australian Preschool Children. Journal of Science and Medicine Sport.

Houston-Wilson, C., Dunn, J.M., van der Mars, H., \& McCubbin, J. (1997). The Effect of Peer Tutors on Motor Performance in Integrated Phyisical Education Classes. Adapted Physical Activity Quarterly.

Iivonen, S. \& Sääkslahti, A. K. (2013). Preschool Children's Fundamental Motor Skills: A Review of Significant Determinants. Early Child Development and Care.

Jenkinson, K., Bendon, A.C., \& Naughton, G. (2013). Peer-Assisted Learning in School Physical Education, Sport and Physical Activity Programmes: A 
Systematic Review. Physical Education and Sport Pedagogy.

Logan, S.W., Robinson, L.E., Wilson, A.E., Lucas, W. A. (2011). Getting the Fundamentals of Movement: A Meta-Analysis of the Effectiveness of Motor Skill Interventions in Children. Child Care Health and Development, 38(3), 305-315.

Lubans, D.R., Morgan, P.J., Cliff, D.P., Barnett, L. M. (2010). Fundamental
Movement Skills in Children and Adolescents: Review of Associated Health Benefits.

Schmidt, R.A, Wrisberg, C. A. (2000). Motor Learning and Performance. Second Edition.

Thomas, J.R. \& French, K. E. (1985). Gender Differences across Age in Motor Performance: a Meta Analysis. 